Krzysztof Kaczmarek

Zaktad Historii Średniowiecznej

Instytut Historii

Uniwersytet im. Adama Mickiewicza, Poznań

\title{
Źródła do dziejów szkół dominikanów poznańskich w dobie nowożytnej
}

Badania nad dziejami szkół i studiów polskich dominikanów mają w rodzimej historiografii długą tradycję. Zainteresowania badawcze autorów podejmujących tę tematykę koncentrowały się jednak, jak dotąd, głównie na epoce średniowiecza i tylko nieliczni historycy podejmowali w swych pracach próbę oświetlenia tego zagadnienia w okresie od XVI do XIX w. ${ }^{1}$

Miano najlepszego znawcy dziejów nowożytnych szkół dominikanów należy bez wątpienia przyznać ojcu R. Świętochowskiemu, który najpierw rozpoznał zasób źródeł oświetlających historię klasztorów dominikańskich w czasach potrydenckich, a następnie przedstawił ówczesną strukturę szkół Braci Kaznodziejów oraz (wraz z A. Chruszczewskim) omówił zagadnienie wyjazdów polskich dominikanów na studia zagraniczne ${ }^{2}$. Ojciec R. Świętochowski udowodnił, że w interesujących go czasach wewnętrzna organizacja szkół dominikańskich była skomplikowana i obejmowała studia o różnym zakresie oddziaływania oraz programie nauczania (od szkół konwentualnych, przez międzyklasztorne szkoły „,materialne”, aż po realizujące uniwersytecki program nauczania teologii studia „formalne” i ,generalne”); wskazał też na najważniejsze, jego zdaniem, ośrodki naukowe na terenie prowincji dominikańskich z ziem polskich (Kraków, Warszawa, Lwów, Wilno, Poznań), omówił zasady ich funkcjonowania, przedstawił „Hektonans pisarzy”, to znaczy

\footnotetext{
${ }^{1}$ Przegląd badań tego zagadnienia w: K. Kaczmarek, Szkoły i studia polskich dominikanów w okresie średniowiecza, Poznań 2005, s. 39-50.

2 Zob. R. Świętochowski, Źródła do dziejów nowożytnych zakonu kaznodziejskiego, Sprawozdania KUL 19 (1970, druk 1972), s. 84-91; idem, Podstawa źródtowa historii dominikanów w Polsce 1772-1970, Sprawozdania KUL 20 (1971), s. 82-89; idem, Szkolnictwo teologiczne dominikanów, w: Dzieje teologii w Polsce, t. 2, red. M. Rechowicz, Lublin 1975, s. 212-285; idem, A. Chruszczewski, Polonia dominicana apud extraneos, w: Studia nad historia dominikanów w Polsce 1222-1972, t. 2, red. J. Kłoczowski, Warszawa 1975 , s. $467-572$.
} 
sylwetki stu zakonników, którzy w czasach nowożytnych zdobyli gruntowne wykształcenie i pozostawili po sobie liczne dzieła teologiczne, a także przywołał kilkuset zakonników, którzy w czasach nowożytnych odbyli peregrynacje naukowe poza granice prowincji ${ }^{3}$.

Zapoczątkowane przez cytowanego autora badania nad nowożytnym szkolnictwem Braci Kaznodziejów zostały jednak po jego śmierci niemal zupełnie zarzucone i dopiero w ostatnich latach podjęto je ponownie - J. Flaga poświęcił kilka studiów środowisku dominikańskich lektorów z XVII i XVIII w., w tym zwłaszcza kwestii ich kompetencji i sposobów powoływania na urząd, A. Wróbel omówił proces nauczania w szkołach dominikańskich na przełomie XVIII i XIX w., a P. Krupa zajął się wykształceniem filozoficznym zakonników ${ }^{4}$. Prace wymienionych autorów należy jednak traktować w kategorii wyjątku od reguły, która mówi, że badania nad nowożytnym szkolnictwem dominikańskim znajdują się ciągle na marginesie współczesnej historiografii poświęconej temu zakonowi, a ich liczba w znaczący sposób odbiega od ogromnej wprost liczby publikacji poświęconej średniowiecznej formacji naukowej braci. Miarą ubóstwa prac na zajmujący nas temat może być fakt, że problematyce wykształcenia dominikanów nie dedykowano nawet jednego opracowania w opublikowanym niedawno tomie studiów poświęconym nowożytnym dziejom tego zakonu na ziemiach polskich ${ }^{5}$.

Ważnym postulatem badawczym w ramach zajmującej nas problematyki jest z pewnością ukazanie funkcjonowania szkół w tych klasztorach, które zostały przez ojca R. Świętochowskiego uznane za najważniejsze ośrodki naukowe zakonu na ziemiach polskich. Ponieważ jednym ze wskazanych przezeń domów był poznański klasztor pod wezwaniem św. Dominika, w niniejszym przyczynku podjąłem próbę określenia podstawy źródłowej, jaką należałoby wykorzystać podejmując w przyszłości zagadnienie działalności szkół w tym domu zakonnym w dobie nowożytnej. Podkreślam przy tym wyraźnie, że moim zamiarem nie jest danie choćby wstępnego zarysu nowożytnego szkolnictwa Braci Kaznodziejów z Poznania, uważam bowiem, że przy obecnej (bardzo słabej) znajomości dziejów klaszoru św. Dominika w XVI-XIX w. jest na to stanowczo za wcześnie. Cel, jaki

${ }^{3}$ R. Świętochowski, Szkolnictwo teologiczne, passim; idem, A. Chruszczewski, Polonia dominicana, passim.

${ }^{4}$ Zob. J. Flaga, Sposób powotywania lektorów w studiach zakonnych w XVII i XVII wieku oraz przystugujace im przywileje, „Roczniki Teologiczne” 42 (1995), z. 4, s. 43-63; idem, Z problematyki funkcjonowania studiów zakonnych w XVII i XVIII wieku, „Roczniki Humanistyczne” 39/40 (1991/1992), nr 2, s. 81-96; A. Wróbel, Nauczanie $w$ średnich szkołach dominikańskich na przełomie XVIII i XIX wieku, „Przegląd Tomistyczny" 3 (1987), s. 343-370; P. Krupa, Wyksztatcenie filozoficzne dominikanów polskich w XVIII stuleciu: Theses ex universa philosophia Ludwika de Mathy OP (1753), w: Dominikanie. Gdańsk - Polska - Europa, red. D.A. Dekański, A. Gołembnika i M. Grubki, Gdańsk - Pelplin 2003, s. 89-115; w sprawie badań nad nowożytnym szkolnictwem dominikanów zob. także H. Gapski, Badania nad przeszłościa dominikanów w Rzeczypospolitej Obojga Narodów. Próba bilansu, w: Dzieje dominikanów w Polsce XIII-XVIII wiek. Historiografia $i$ warsztat badawczy historyka, red. H. Gapski, J. Kłoczowski i J.A. Spież, Lublin 2006, s. 61-62.

${ }_{5}$ Dominikanie na ziemiach polskich $w$ epoce nowożytnej, red. A. Markiewicz i M. Miławicki, Kraków 2009 (Studia i Źródła Dominikańskiego Instyutu Historycznego w Krakowie, t. 5). Już w trakcie druku niniejszego opracowania ukazała się praca M. Miławickiego i W. Szymborskiego, ,, Vir sapientiae et morum provitate clarus", Regensi studium generalnego polskiej prowincji dominikanów w XVII w., Przegląd Tomistyczny 16 (2010), s. 125-225; także M. Zdanek, Regensi dominikańskiego studium generalnego w Krakowie do 1596 r., tamże, s. 77-124. 
przed sobą stawiam, jest znacznie skromniejszy: chciałbym zidentyfikować i poddać krótkiej charakterystyce te przekazy źródłowe, które zawierają dane o funkcjonowaniu szkół w murach poznańskiego klasztoru w epoce potrydenckiej i traktuję niniejsze uwagi w charakterze wprowadzenia do dalszych, bardziej wnikliwych, badań nad wykształceniem poznańskich dominikanów w XVI-XIX w.

Spuścizna źródłowa pozostała po klasztorze poznańskich dominikanów jest obfita, szczególnie dla interesującego mnie w tym miejscu okresu nowożytnego. Podejmując się krótkiej charakterystyki tych zabytków w perspektywie badań nad szkołami Braci Kaznodziejów należy w pierwszej kolejności podkreślić, że - z dwoma wyjątkami - wszystkie źródła do nowożytnych dziejów dominikanów z klasztoru św. Dominika pozostają pod postacią rękopisów. Wyjątki, o których mowa, dotyczą niektórych nowożytnych protokołów z obrad kapituł polskiej prowincji dominikańskiej oraz nekrologu konwentu. Pierwsze edycje uchwał XVI-wiecznych kapituł polskiej prowincji dominikańskiej pojawiły się już w okresie międzywojennym; przygotował je do druku ksiądz K. Kantak przy okazji swych studiów nad klasztorem poznańskim ${ }^{6}$. W następnych latach do projektu ich wydawania powrócił ojciec R. Madura, który po długich przygotowaniach opublikował w roku 1972 pierwszy tom akt kapituł obejmujący okres do roku $1600^{7}$. Doceniając edytorski wysiłek obu przywołanych autorów, trzeba jednak podkreślić, że znakomita większość nowożytnych akt dominikańskich kapituł z ziem polskich nie została, jak dotąd, wydana drukiem, chociaż ojciec Madura poczynił ku temu odpowiednie przygotowania - zebrane przezeń materiały obejmujące uchwały kapituł z XVII, XVIII i XIX w. są obecnie przechowywane pod postacią maszynopisów w Archiwum Polskiej Prowincji Dominikańskiej w Krakowie ${ }^{8}$. Jeśli chodzi o nekrolog poznańskiego konwentu św. Dominika, to pierwszeństwo w przygotowaniu jego edycji należy ponownie przyznać ks. K. Kantakowi, który w 1935 r. opublikował ten mortuarz na łamach „Kroniki Miasta Poznania”. Wydanie to miało jednak, niestety, tyle niedociągnięć, że w ostatnich latach trzeba było przygotować reedycję rzeczonego zabytku ${ }^{10}$. Zarówno akta nowożytnych kapituł polskich dominikanów, jak i przywołany wyżej najstarszy zachowany do naszych czasów nekrolog konwentu są zabytkami, które muszą być uwzględniane w czasie kwerendy, której celem będzie zgromadzenie danych, niezbędnych do oświetlenia szkół poznańskich dominikanów w XVI-XIX w.

${ }^{6}$ K. Kantak, Przyczynki do dziejów dominikanów poznańskich, „Kronika Miasta Poznania” 5 (1927), s. 867-874 (cyt. dalej: KMP); idem, Dalsze przyczynki do dziejów dominikanów poznańskich, KMP 8 (1930), s. $335-342$.

7 Acta Capitulorum Provinciae Poloniae Ordinis Praedicatorum, t. 1 (ab anno 1225 ad annum 1600 celebratorum), ed. R. F. Madura, Romae 1972.

${ }^{8}$ Acta Capitulorum Provinciae Poloniae Ordinis Praedicatorum, t. 2 (ab anno 1603-1700), maszynopis; Acta Capitulorum Provinciae Poloniae Ordinis Praedicatorum, t. 3 (a. 1701-1800), maszynopis; Acta Capitulorum Provinciae Poloniae Ordinis Praedicatorum, t. 4 (ab anno 1801-1863 et ab anno 1920-1978), maszynopis; ogólną charakterystykę części tych materiałów dał J. Kłoczowski, Kapituly polskiej prowincji dominikańskiej w XVII wieku, w: Podtug nieba i zwyczaju ziemskiego. Studia z dziejów architektury, sztuki i kultury ofiarowane Adamowi Miłobędzkiemu, Warszawa 1988, s. 539-544; idem, Kapituly polskiej prowincji dominikańskiej w czasach saskich (1697-1772/1773), Sobótka 37 (1982), nr 3-4, s. 491-496.

9 Kalendarz dominikanów poznańskich, wyd. K. Kantak, KMP 13 (1935), s. 398-406.

10 Zob. K. Kaczmarek, Nekrolog dominikanów poznańskich, „Studia Źródłoznawcze” 43 (2005), s. 125-150. 
O wiele więcej informacji na interesujący nas temat można odnaleźć w rękopiśmiennej spuściźnie pozostałej po dominikanach z Poznania, przechowywanej w archiwach państwowych i kościelnych. Instytucją, która dysponuje bez wątpienia największym zbiorem manuskryptów po konwencie św. Dominika jest poznańskie Archiwum Państwowe, które posiada kolekcję licznych dyplomów i akt tego domu zakonnego z okresu od XIII do XIX w. ${ }^{11}$ Poza pewną liczbą dokumentów, w których zostali wymienieni czynni w danym momencie klasztorni lektorzy teologii ${ }^{12}$, dwoma z pewnością najważniejszymi zabytkami oświetlającymi działalność szkolną konwentu są: nekrolog pisany w klasztorze poznańskich dominikanów pod koniec XVIII i w XIX w., w którym zostali wymienieni liczni lektorzy teologii oraz posiadacze stopni naukowych w tej dyscyplinie wywodzący się z konwentu św. Dominika ${ }^{13}$, a także księga uchwał rady konwentu poznańskiego, zapoczątkowana w roku 1724 w okresie rządów przeora Kandyda Nadalińskiego i prowadzona aż do roku $1822^{14}$.

Drugi co do wielkości zbiór archiwaliów podominikańskich z Poznania znajduje się w chwili obecnej w miejscowym Archiwum Archidiecezjalnym ${ }^{15}$. Materiały tam zgromadzone można podzielić na kilka części. Do pierwszej z nich należą sporządzone na użytek klasztoru poznańskiego kopie uchwał kapituł generalnych i prowincjalnych z XVI-XVIII w.; do drugiej liczne akta o charakterze gospodarczym, w tym zwłaszcza księgi dochodów i wydatków klasztornych z XVIII w.; trzecia - bardzo obszerna - część omawianego zasobu archiwalnego obejmuje dokumentację funkcjonowania poznańskiego Bractwa Różańcowego; do czwartej zaś - z punktu widzenia niniejszego opracowania bez wątpienia najważniejszej - części dominicaliów przechowywanych w poznańskim Archiwum Archidiecezjalnym należą źródła o charakterze prozopograficznym, w tym zwłaszcza metryka konwentu, w której odnotowano informacje o składanych w klasztorze profesjach w okresie od ostatniej ćwierci XVI do początku XIX w. ${ }^{16}$ Ostatni z ważnych dla omawianego tematu zbiór materiałów oświetlających nowożytne dzieje poznańskiego konwentu

${ }^{11}$ Warto przy tym podkreślić, że jest to w ogóle największy zbiór materiałów poklaszornych znajdujących się w tym archiwum - zob. Z. Wojciechowska, Dokumenty i akta klasztorne w Archiwum Państwowym w Poznaniu - dzieje, zawartość i metody opracowania, „Poznański Rocznik Archiwalno-Historyczny” 4 (1996, wyd. 1997), s. 57-72.

12 Zob. na przykład APP, sygn. Dominikanie Poznań D. 35 (dokument z 1528 r., w którym występują lektorzy: Mikołaj z Gostynia i Tomasz); D. 41 (dokument ze stycznia 1580 roku wzmiankujący osobę lektora Franciszka za Lwowa); D. 45 (dokument ze stycznia 1586, w którym pojawiają się postaci przeora i zarazem doktora teologii Seweryna oraz mistrza nowicjatu Krzysztofa); por. także Kopiarz dokumentów i przywilejów dla klasztoru dominikanów w Poznaniu z lat 1244-1643, APP, sygn. Dominikanie Poznań 72.

${ }_{13}$ Catalogus Mortuum Conscriptus pro Conventu Formali Posnaniensi Anno Domini 1798, AAP, sygn. Dominikanie Poznań 75.

${ }^{14}$ Liber Consiliorum Conventus Posnaniensis sub prioratu Admodum Reverendi Prioris Sacrae Theologiae Lectoris Patris Candidi Nadaliński Anno Domini 1724 die 24 Ianuarii inchoatus, APP, sygn. Dominikanie 74 (cyt. dalej LCCP).

15 Archiwum Archidiecezjalne w Poznaniu, sygn. AZ 5/5 - AZ5/17 (cyt. dalej: AAP).

16 AAP, sygn. AZ 5/6 (Metrica Fratrum, Professorum in conventu Posnaniensi Sancti Dominici Ordinis Praedicatorum ab 1576 sub Provincialatu RPF Georgii Trebnic sub Prioratu RPF Hyacinthi Choryński STB a Fratre Luca Plessoviense renovata et ex Authentico fideliter Transumpta atque ad modellum delinaetus redacta cyt. dalej: Metryka). 
św. Dominika i studia zamieszkujących w nim zakonników znajduje się w Archiwum Polskiej Prowincji Dominikanów w Krakowie - należą do niego: kopiarz klasztornych dokumentów ${ }^{17}$, nie wydane dotąd drukiem protokoły z obrad nowożytnych kapituł polskiej prowincji dominikańskiej ${ }^{18}$, księga dominikańskiego Studium Generalnego w Krakowie $^{19}$ (bez wątpienia najważniejszego miejsca, w którym polscy dominikanie odbywali studia wyższe), a także liczne protokoły z posiedzeń rady polskiej prowincji dominikańskiej ${ }^{20}$.

Podejmując próbę ukazania wartości, jaką zawarte w powyższych przekazach informacje mają dla odtworzenia działalności nowożytnych szkół poznańskich dominikanów, trzeba najpierw przypomnieć, że w najnowszej literaturze przedmiotu poświęconej systemowi dominikańskiej edukacji dominuje pogląd, że kształcenie profesów zaczynało się z chwilą ich wstąpienia do nowicjatu, zaś ostatnim jego etapem były studia wyższe odbywane na uniwersytetach lub we własnych, zakonnych, Studiach Generalnych ${ }^{21}$. Pamiętając o tym założeniu spróbujmy zatem pokazać, jakie możliwości zrekonstruowania procesu edukacji poznańskich dominikanów w dobie nowożytnej tkwią w przywołanych wyżej przekazach.

W pierwszej kolejności trzeba podkreślić, że źródła te umożlliwiają precyzyjne odtworzenie sposobu prowadzenia przez poznański klasztor nowicjatu. Bardzo cenne informacje w tej sprawie przynosi anonsowana wyżej Metryka konwentu św. Dominika ${ }^{22}$. Pozwala ona oszacować skalę rekrutacji prowadzonej przez poznański klasztor (od ostatniej ćwierci XVI w. do wydania przez władze pruskie zakazu przyjmowania nowych kandydatów do życia w zakonie w początkach wieku XIX zakonne śluby złożyło w nim 849 nowicjuszy), podaje dokładne dane osobowe osób wstępujących do klasztoru, to znaczy ich wiek, daty złożenia przez nich profesji i listę świadków tego wydarzenia, a także imiona oraz stopnie naukowe mistrzów nowicjatu, wprowadzających młodych adeptów życia zakonnego w jego najważniejsze tajniki. Ta ostatnia kwestia, to znaczy imiona i kompetencje osób odpowiedzialnych za funkcjonowanie w Poznaniu nowicjatu, a także czas pełnienia przez nie urzędu mistrza nowicjuszy jest dodatkowo dokumentowana przez niektóre zapiski zawarte w Liber Consiliorum konwentu św. Dominika. Wyłącznie tytułem dania przykładu takich zapisów można się w tym miejscu odwołać do uchwały podjętej przez radę klasztoru w dniu 9 października 1724 r., w której czytamy o złożeniu funkcji magi-

\footnotetext{
17 Copiarium privilegiorum et aliorum documentorum conventus Posnaniensis Ordinis Praedicatorum ab anno 1244-1858, Archiwum Polskiej Prowincji Dominkanów w Krakowie (cyt. dalej APPDK), sygn. Pzd 1.

18 Zob. wyżej przypis nr 8.

${ }^{19}$ Liber Studii Generalis Cracoviensis, APPDK, sygn. Kr 20.

${ }^{20}$ Liber Consiliorum Provinciae Poloniae Ordinis Praedicatorum ab anno 1610 die 19 Maii usque ad annum 1627, APPDK, sygn. Pp 37; Liber Consiliorum Provinciae Poloniae Ordinis Praedicatorum sub Admodum Reverendo Patre Fratre Ioanne Waxman S.T.M. Provinciali Poloniae Ordinis Fratrum Praedicatorum ab Anno Domini MDCLXXIV die XIII May, APPDK, sygn. Pp 38; Liber Consiliorum Provinciae Poloniae sub ARPF Georgis Trebnic STM Provinciali Poloniae Ordinis FF Praedicatorum ab anno 1631 die 10 May, APPDK, sygn. Pp 155.

${ }^{21}$ W tej sprawie zob. M. Mulchachey, ,First the Bow is bent in Study...”. Dominican Education before 1530, Toronto 1998, s. 79; także K. Kaczmarek, Szkoły i studia ..., s. 56.

${ }^{22}$ Zob. wyżej, przypis 16 .
} 
stra novitiorum przez brata Wojciecha Bielowskiego i wyznaczeniu na jego miejsce profesa Hieronima Szpytmanowskiego ${ }^{23}$.

Możliwość prześledzenia sposobu, w jaki funkcjonował nowicjat, nie jest jedyną korzyścią, jaka płynie z analizy przywołanych wyżej materiałów. Cytowane wcześniej nowożytne manuskrypty podominikańskie z Poznania umożliwiają także postawienie tezy o ciągłym funkcjonowaniu w murach tego domu zakonnego konwentualnego studium teologii - dowody na stałą obecność tego typu szkoły u poznańskich dominikanów dają liczne wzmianki o lektorach teologii, prowadzących zajęcia w klasztornej szkole. Wzmianki te odnajdujemy w źródłach dokumentowych ${ }^{24}$, nekrologach konwentu, zachowanych aktach kapituł prowincjalnych, jak i w przekazach aktowych, w tym zwłaszcza w klasztornej Liber Consiliorum. Zastrzegając wyraźnie, że przywołane niżej imiona poznańskich lektorów traktuję wyłącznie jako przykłady tychże, dla udokumentowania postawionej wyżej tezy pozwolę sobie przytoczyć w tym miejscu kilka takich zapisów. Zachowane kommemoracje w nekrologach spisanych w poznańskim klasztorze wzmiankują na przykład lektora Tomasza, zmarłego w dniu 18 marca $1528 \mathrm{r}^{25}$, lektora Mariusza Skąpskiego ${ }^{26}$, lektora Felicjana Nowackiego, ${ }^{27}$ zmarłego w dniu 2 stycznia 1796 r. lektora Bazylego Żebrowskiego $^{28}$, lektora Wincentego Łaniewskiego zmarłego w dniu 1 stycznia $1809 \mathrm{r}^{29}$, czy też zmarłego w dniu 17 lutego 1812 r. w Brodnicy lektora Nepomucena Raczyńskiego ${ }^{30}$. Osoby lektorów wykładających teologię w szkole poznańskiej występują także na kartach Liber Consiliorum konwentu św. Dominika. Z zachowanych tam zapisek wynika w sposób jednoznaczny, że lektorzy wraz z przeorami, podprzeorami, mistrzami nowicjatu i kilkoma innymi zakonnikami wchodzili w skład klasztornej rady, niejako z urzędu brali udział w jej posiedzeniach i własnoręcznymi podpisami sygnowali protokoły z jej obrad. W takich właśnie okolicznościach występują w rzeczonym źródle na przykład osoby działających w latach dwudziestych XVIII w. lektorów poznańskich: Wojciecha Balcerkowicza, Apolinarego Bielowicza, Wojciecha Bilowicza oraz Franciszka Pędzińskiego ${ }^{31}$. Analiza wskazanych zapisków daje więc nie tylko możliwość odtworzenia obsady konwentualnej szkoły teologii działajacej w klasztorze poznańskim, ale pozwala także na uściślenie chronologii pełnienia przez kolejnych lektorów ich funkcji i daje pewne wyobrażenie o ich własnym wykształceniu (przy zapiskach dotyczących wzmiankowanych osób występują adnotacje dotyczące ich stopni naukowych). Istotne informacje dotyczące działalności konwentualnej szkoły teologii u poznańskich dominikanów przynoszą także zachowane do naszych czasów, choć w większości w dalszym ciągu pozbawione krytycznego wydania, protokoły z obrad kapituł polskiej prowincji domi-

\footnotetext{
${ }^{23}$ LCCP, s. 9.

${ }^{24}$ Zob. wyżej, przyp. 12.

${ }^{25}$ K. Kaczmarek, Nekrolog..., s. 139.

${ }^{26}$ Cathalogus mortuum..., fol. 13.

${ }^{27}$ Ibidem, fol. 45.

28 Ibidem, fol. 4.

29 Ibidem, fol. 3.

${ }^{30}$ Ibidem, fol. 51.

31 LCCP, s. 7-27.
} 
nikańskiej z XVI-XIX w. ${ }^{32}$ Są one ważne, zawierają bowiem tak zwane Provisiones studiorum, to znaczy wydawane na posiedzeniach kapituł rozporządzenia dotyczące lokalizacji oraz obsady działających na terenie prowincji szkół, w tym także konwentualnych studiów teologicznych. Dla wykazania ich użyteczności dla omawianej kwestii wystarczy choćby kilka przykładów wyjętych z akt XVI-wiecznych, a także z niepublikowanych protokołów z samego początku XVII w. I tak w roku 1583 kapituła sandomierska skierowała do Poznania brata Wincentego, kapłana (sacerdos) i bakałarza teologii, w charakterze lektora i magistra nowicjuszy ${ }^{33}$. Kapituła zwołana do Warki w roku 1593 asygnowała do Poznania pro lectore, brata Melchiora z Warki ${ }^{34}$. W 1603, w czasie obrad w Poznaniu, kapituła prowincji wydała decyzję o skierowaniu do klasztoru św. Dominika trzech lektorów teologii. Funkcję ,pierwszego lektora” (lector primarius) miał odtąd pełnić w konwencie poznańskim bakałarz teologii, brat Abraham Bzowski, drugim lektorem został mianowany brat Gaspar z Warki, trzecim zaś (pro lectore tertio) wyznaczono profesa Błażeja ${ }^{35}$. W czasie obrad kapituły prowincjalnej w Warszawie w roku 1605 do klasztoru poznańskiego asygnowano Waleriana Litewczyka, w charakterze drugiego lektora (pro lectore secundario) oraz brata Kamila Jasińskiego, którego wyznaczono trzecim lektorem konwentu św. Dominika (pro tertio lectore) ${ }^{36}$. Dwa lata później (1607) kapituła prowincjalna zwołana do Lublina wyznaczyła w klasztorze poznańskim trzeciego lektora teologii w osobie miejscowego profesa, brata Łukasza z Szamotu1 ${ }^{37}$. Wykładowców w szkole konwentualnej w Poznaniu wyznaczyła również kapituła z roku 1609 obradująca w Przemyślu. W protokole zawierającym jej postanowienia odnajdujemy mianowania dla wszystkich trzech lektorów mających wykładać w tym studium ${ }^{38}$. Podobne decyzje zapadły także w czasie obrad kapituły warszawskiej z roku 1616, kiedy to asygnowano do Poznania pierwszego lektora w osobie brata Felicjana, drugiego lektora, którym został Piotr z Przemyśla, a także Bernarda „Seretiusa”, który otrzymał nominację pro tertio lector ${ }^{39}$. Wreszcie - by zakończyć już wątek znaczenia akt kapituł prowincjalnych dla odtworzenia działalności konwentualnego studium teologii u poznańskich dominikanów - można odwołać się jeszcze do akt kapituły krakowskiej z roku 1627. W protokole z jej obrad także odnajdujemy nominacje dla lektorów, którzy mieli się udać do klasztoru św. Dominika ${ }^{40}$. Ważne dane o poznańskich lektorach teologii przynosi także anonsowana wyżej nowożytna Księga krakowskiego Studium Generalnego. Na jej kartach odnajdujemy na przykład informacje o dokładnych terminach składania przez poznańskich profesów egzaminów lektor-

\footnotetext{
32 Zob. wyżej, przypisy 7 i 8.

${ }_{33}$ Acta Capitulorum Provinciae Poloniae Ordinis Praedicatorum, t. 1 (ab anno 1225 ad annum 1600 celebratorum), s. 448.

34 Ibidem, s. 497.

${ }^{35}$ Acta Capitulorum Provinciae Poloniae Ordinis Praedicatorum, t. 2 (ab anno 1603-1700), s. 13 (maszynopis).

36 Ibidem, s. 33.

${ }^{37}$ Ibidem, s. 63.

38 Ibidem, s. 103.

39 Ibidem, s. 223.

40 Ibidem, s. 420.
} 
skich - w dniu 9 maja 1736 r. egzamin na lektora artium i teologii złożył brat Kandyd Szember, nieco później (19 września tego samego roku) podobną procedurę przeszedł profes Rajmund Kręcki, zaraz potem (22 września 1736 r.) na lektora promowano późniejszego przeora poznańskiego konwentu Piotra Rogo oraz (w dniu 25 września) brata Meynarda Tierfelda ${ }^{41}$. Naturalnie nie są to wszystkie tego typu wiadomości zapisane w źródle - dla potrzeb niniejszej pracy przywołałem tylko kilka wybranych postaci lektorów, których cechą wspólną jest to, że złożyli stosowne egzaminy w jednym miesiącu $1736 \mathrm{r}$.

Klasztor poznański - niezależnie od tego, że prowadził nowicjat i konwentualne studium teologii - był także siedzibą szkół o szerszym, międzyklasztornym zasięgu. Znaczącą rolę $\mathrm{w}$ organizowaniu nauczania na tym poziomie dom ten odgrywał już w epoce średniowiecza i utrzymał ją także w okresie nowożytnym ${ }^{42}$. Według ustaleń ojca R. Świętochowskiego potencjał intelektualny miejscowych zakonników był w tych czasach na tyle duży, że w roku 1618 bracia wystąpili z projektem zorganizowania w konwencie św. Dominika zakonnego Studium Generalnego. Co prawda ten ambitny projekt nie został zrealizowany z uwagi na gwałtowny sprzeciw dominikanów związanych z taką samą szkołą działającą w Krakowie, ale mimo to dom w Poznaniu był na tyle znaczącym ośrodkiem studiów teologicznych, że pod koniec XVII w. utworzono w jego murach tak zwane „studium formalne" - szkołę teologiczną o uniwersyteckim poziomie nauczania, jednak bez prawa do nadawania stopni naukowych; obok niej w klasztorze św. Dominika działała także szkoła międzyklasztorna o profilu filozoficznym, określana mianem ,studium materialnego" $"$.

Wszystkie wskazane typy nowożytnych źródeł oświetlających dzieje poznańskiego klasztoru Dominikanów można i trzeba wykorzystać także do analizy funkcjonowania tamtejszych szkół międzyklasztornych o profilu filozoficzno-teologicznym. Działalność różnych typów takich szkół poświadczają choćby nowożytne akta kapituł prowincjalnych, w których odnajdujemy asygnacje dla wykładowców oraz studentów tych szkół. Dla przykładu - jako ośrodek szkolny o partykularnym (międzyklasztornym) charakterze klasztor poznański został wskazany w protokole kapituły sandomierskiej z roku 1507, kapituły ze Żnina z roku 1510, oraz kapituły z Bochni z roku 151244. O działalności takich studiów w tym domu zakonnym w następnych latach świadczą także nominacje dla ich wykładowców zapisane w protokołach kapituł z Łowicza (1514) oraz Chełmna (1519) ${ }^{45}$. Stosowne adnotacje $\mathrm{w}$ tej sprawie są także zawarte w cytowanych protokołach kapituł z początku XVII w. Na kapitule lubelskiej w roku 1607 zadecydowano na przykład o przeniesieniu profesa lubelskiego Cypriana do Poznania pro studio ${ }^{46}$. W tym samym celu asygnowała do

${ }^{41}$ Liber Studii Generalis Cracoviensis, fol. 453-454.

${ }^{42} \mathrm{Na}$ ten temat zob. K. Kaczmarek, Szkoty i studia..., s. 208-310.

43 R. Świętochowski, Szkolnictwo teologiczne dominikanów, s. 213 i 247.

${ }^{44}$ Acta Capitulorum Provinciae Poloniae Ordinis Praedicatorum, t. 1 (ab anno 1225 ad annum 1600 celebratorum), s. 166, 179 i 189.

45 Ibidem, s. 208 i 257-258.

${ }^{46}$ Acta Capitulorum Provinciae Poloniae Ordinis Praedicatorum, t. 2 (ab anno 1603-1700), s. 65 (maszynopis). 
klasztoru poznańskiego trzech zakonników kapituła piotrkowska z 1618 r. ${ }^{47}$ Z kolei kapituła obradująca w Krakowie w roku 1627 podjęłą decyzję o skierowaniu do konwentu św. Dominika brata Erazma pro lectore Physice, a także Justyniana Zaleskiego na studia teologiczne (pro studio Theologiae) ${ }^{48}$. Wykładowców nauczających w działającej w poznańskim klasztorze szkole filozoficznej przywołuje także cytowana wcześniej Metryka konwentu św. Dominika, głównie z tego powodu, że zakonnicy ci często pełnili dodatkowo funkcję magistrów nowicjuszy. Stąd wiadomo na przykład, że w roku 1698 profesorem filozofii był w Poznaniu brat Hieronim Szmatrowicz ${ }^{49}$. W następnym roku tę samą funkcję pełnił brat Kazimierz Dylagowicz ${ }^{50}$, zaś w roku 1707 filozofię wykładał braciom Tymoteusz Balaszewski ${ }^{51}$. To samo źródło przywołuje osobę brata Franciszka Pędzińskiego, profesora filozofii w szkole poznańskiej w roku $1720^{52}$, a także wykładajacego tamże w następnych latach (1724) Wojciecha Bilowicza ${ }^{53}$, czy Kandyda Szembera (1736) ${ }^{54}$. Choć oczywiście nie są to wszystkie możliwe przykłady odnotowanych w źródłach lektorów szkół partykularnych działających w klasztorze poznańskim w XVI-XIX w., ich przywołanie dobrze dokumentuje funkcjonowanie w nim w interesującym nas okresie tego typu studiów. Bardzo istotne dane o funkcjonowaniu szkoły „formalnej” w klasztorze poznańskim przynosi także Liber Studium Generalnego w Krakowie - na jej kartach odnajdujemy liczne informacje o promowaniu poznańskich zakonników do stopnia bakałarza, prezentata i magistra teologii wraz z adnotacjami o ich wcześniejszej działalności szkolnej. W zapisce informującej o nadaniu bratu Wojciechowi Balcerkowiczowi stopnia prezentata teologii z dnia 13 lutego 1727 r. czytamy na przykład, że wcześniej zakonnik ten przez dwa lata wykładał filozofię w poznańskim studium „formalnym”55. Promowany na prezentata w dniu 18 września 1747 r. profes poznański Berengar Rudzki miał znacznie dłuższy staż nauczyciela w tej szkole - wykładał w niej bowiem filozofię przez dwa lata, a teologię spekulatywną przez lat sześćc ${ }^{56}$. Także dwa lata wykładali filozofię w studium poznańskim promowani na prezentatów w dniu 6 października 1746 r.: Piotr Rogo oraz Grzegorz Święciszkiewicz; ten ostatni nauczał tam nadto przez sześć lat teologii spekulatywnej ${ }^{57}$. Dwuletni staż nauczyciela w poznańskiej szkole miał również promowany na prezentata w dniu 12 lipca 1785 r. - Tadeusz Rosa ${ }^{58}$.

Z przeprowadzonego przeglądu źródeł do dziejów konwentu św. Dominika w Poznaniu widać więc wyraźnie, że choć w archiwalnej spuściźnie, jaka pozostała po tym domu

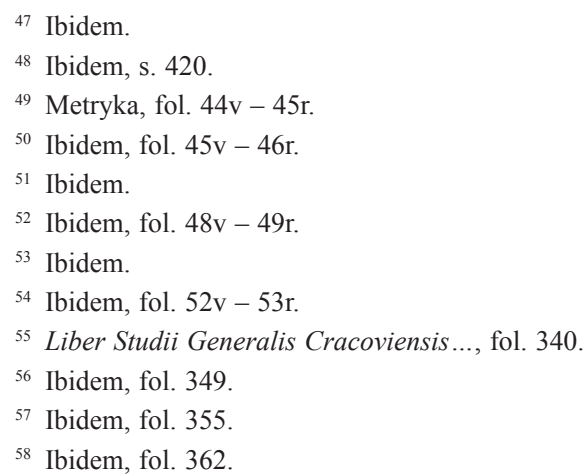


zakonnym nie zachowały się teksty w sposób bezpośredni dokumentujace działalność istniejących w jego murach szkół, istnieje szereg przekazów, które w sposób pośredni dowodzą ich funkcjonowania i pozwalają wyciągać interesujace wnioski o edukacyjnej roli poznańskiego domu Braci Kaznodziejów w okresie potrydenckim. Dokładna analiza tych tekstów jawi się w konsekwencji niniejszych rozważań jako pilny postulat badawczy.

\title{
Sources for the history of the schools run by the Dominican Order in modern times
}

\begin{abstract}
Summary
The present work aims at presenting the most important texts documenting the activity of schools in the St. Dominic Monastery in Poznań in modern times. Following a query carried out in archives, the author made a juxtaposition of relevant texts. It appears that that the most precious monuments shedding light on the Dominican educational system are to be found in Poznań-based archives and registry offices, and in the Archives of the Polish Province of Dominicans in Cracow. The archival material includes documents written by Dominicans, as well as numerous records and documents that provide detailed information on schools operating within the order and on their lecturers and disciples.
\end{abstract}

